\title{
Boosted Membrane Potential as Bioenergetic Response to Anoxia in Dinoroseobacter shibae
}

Christian Kirchhoff and Heribert Cypionka*

Institute for Chemistry and Biology of the Marine Environment, Carl-von-Ossietzky University of Oldenburg, Oldenburg, Germany

Dinoroseobacter shibae DFL $12^{\top}$ is a metabolically versatile member of the world-wide abundant Roseobacter clade. As an epibiont of dinoflagellates $D$. shibae is subjected to rigorous changes in oxygen availability. It has been shown that it loses up to $90 \%$ of its intracellular ATP when exposed to anoxic conditions. Yet, $D$. shibae regenerates its ATP level quickly when oxygen becomes available again. In the present study we focused on the bioenergetic aspects of the quick recovery and hypothesized that the proton-motive force decreases during anoxia and gets restored upon re-aeration. Therefore, we analyzed $\Delta \mathrm{pH}$ and the membrane potential $(\Delta \Psi)$ during the oxic-anoxic transitions. To visualize changes of $\Delta \Psi$ we used fluorescence microscopy and the carbocyanine dyes $\mathrm{DiOC}_{2}$ (3; 3,3'-Diethyloxacarbocyanine lodide) and JC-10. In control experiments the $\Delta \Psi$-decreasing effects of the chemiosmotic inhibitors CCCP (carbonyl cyanide m-chlorophenyl hydrazone), TCS (3,3', 4',5-tetrachlorosalicylanilide) and gramicidin were tested on $D$. shibae and Gram-negative and -positive control bacteria (Escherichia coli and Micrococcus luteus). We found that $\Delta \mathrm{pH}$ is not affected by short-term anoxia and does not contribute to the quick ATP regeneration in $D$. shibae. By contrast, $\Delta \Psi$ was increased during anoxia, which was astonishing since none of the control organisms behaved that way. Our study shows physiological and bioenergetical aspects comparing to previous studies on transcriptomic responses to the transition from aerobic to nitrate respiration in $D$. shibae. For the lifestyle as an epibiont of a dinoflagellate, the ability to stand phases of temporary oxygen depletion is beneficial. With a boosted $\Delta \Psi$, the cells are able to give their ATP regeneration a flying start, once oxygen is available again.

Keywords: proton-motive force, Roseobacter clade, Micrococcus luteus, short-term anoxia, intracellular pH, fluorescence microscopy, $\mathrm{DiOC}_{2}(3), \mathrm{JC}-10$

\section{INTRODUCTION}

Dinoroseobacter shibae is a member of the metabolically versatile Roseobacter clade and can be found in marine and fresh water habitats world-wide (Kolber et al., 2001; Béjà et al., 2002). It belongs to the aerobic anoxygenically phototrophic bacteria. Accordingly, it was documented that light supports proton translocation and therefore contributes to the ATP regeneration in D. shibae (Holert et al., 2011). However, the cells are able to switch from an aerobic to anaerobic lifestyle (Piekarski et al., 2009). As epibionts of dinoflagellates (Biebl et al., 2005) that can shuttle between oxic and anoxic conditions (Wagner-Döbler et al., 2010), this versatility may be helpful.

The oxic-anoxic shift causes dramatic changes of the cell physiology. Laass et al. (2014) reported that $D$. shibae undergoes a metabolic crisis during the transition from aerobic to anaerobic growth 
with nitrate. Transcriptomic analysis showed that protein biosynthesis in $D$. shibae is reduced during this phase. The energy balance is disturbed and accumulation of TCA-cycle intermediates can be observed until the cells adapt to nitrate as electron acceptor (Laass et al., 2014). Comparably, it was found that the cells lose up to $90 \%$ of their ATP when incubated anoxically for $2 \mathrm{~h}$. However, they show remarkably fast ATP regeneration upon re-aeration and exposure to light. Within only $40 \mathrm{~s}$ the cells recovered by producing up to $12 \mathrm{mM}$ of intracellular ATP (Holert et al., 2011, see also our experiments in Supplement 1).

The mechanisms behind the fast recovery of the energy charge after anoxia are not clear yet. In the present study we addressed the bioenergetics of short-term anoxia and the quick ATP recovery in $D$. shibae. We hypothesized that the proton-motive force is involved, assuming that it would be low in de-energized cells and increase during recovery. Therefore we analyzed $\Delta \mathrm{pH}$ and $\Delta \Psi$ during oxic-anoxic transitions. Membrane-potential disrupting ionophores and some other bacteria were used for control experiments. Analysis of the intracellular $\mathrm{pH}$ was performed via butanol permeabilization after Scholes and Mitchell (1970). Two carbocyanine dyes were used to visualize the membrane potential by fluorescence microscopy. As hypothesized we found changes of the proton-motive force, but quite different from our expectations.

\section{MATERIALS AND METHODS}

\section{Bacterial Strains and Cultivation}

Dinoroseobacter shibae DFL $12^{\mathrm{T}}$ (Biebl et al., 2005) was grown in artificial seawater medium (SWM) with $10 \mathrm{mM}$ succinate as sole electron and carbon source (Supplement 2 for all media). Cells were cultivated in a diurnal light/dark rhythm $(12 \mathrm{~h} / 12 \mathrm{~h}$, $12 \mu \mathrm{mol}$ photons $\mathrm{m}^{-2} \mathrm{~s}^{-1}$ ) in a shaker at $25^{\circ} \mathrm{C}$ and $125 \mathrm{rpm}$ (Soora and Cypionka, 2013). Control organisms Escherichia coli (strain K12) and Micrococcus luteus (strain E10-2, Batzke et al., 2007) were grown on LB medium at $33^{\circ} \mathrm{C}$.

\section{Determination of the Intracellular $\mathrm{pH}\left(\mathrm{pH}_{\mathrm{i}}\right)$}

The determination of the intracellular $\mathrm{pH}$ was performed after Scholes and Mitchell (1970) via permeabilization of the membrane with $5 \%(\mathrm{vol} / \mathrm{vol})$ butanol. Cells were harvested by centrifugation $\left(150 \mathrm{ml}\right.$ culture, $10.000 \times \mathrm{g}, 10 \mathrm{~min}, 4^{\circ} \mathrm{C}$, Beckman J2-HS), the supernatant was discarded and the pellet was resuspended in $5 \mathrm{ml}$ of non-buffered solution $(0.3 \mathrm{M} \mathrm{NaCl}$, $\mathrm{pH}$ 7). The measurement was performed in a $5 \mathrm{ml}$ glass tube with an $\mathrm{OD}_{436}$ of 20 . For the determination of the $\mathrm{pH}_{\mathrm{i}}$ under anoxic conditions the glass tube was closed with a rubber stopper and flushed with $\mathrm{N}_{2}$ for 2 h. A pH electrode (type Inlab Micro, Mettler Toledo) was immersed and the suspension was stirred. The data were logged (AD converter ADC-16, pico Technology) with the software MPwin (version 2008.08.25, Cypionka, 2005). For permeabilization $250 \mu \mathrm{l}$ of butanol were added into the stirred suspension. From the $\mathrm{pH}$ changes after butanol addition at different outer $\mathrm{pH}$ values, the $\mathrm{pH}_{\mathrm{i}}$ could be determined.

\section{Application of Short-term Anoxia and Subsequent Re-aeration}

Exponentially growing cells $(5 \mathrm{ml})$ were taken directly for $\Delta \Psi$ analysis. Additionally, two more aliquots (each $5 \mathrm{ml}$ ) were transferred into glass tubes closed by rubber stoppers. The tubes were permanently protected from light by aluminum foil during further treatment. Both tubes were flushed with $\mathrm{N}_{2}$ to quickly establish anoxic conditions. After $2 \mathrm{~h}$ incubation at $25^{\circ} \mathrm{C}$, one of the tubes was flushed for $2 \mathrm{~min}$ with air under light exposure (420 $\mu \mathrm{mol}$ photons $\mathrm{m}^{-2} \mathrm{~s}^{-1}$ ) to allow recovery of the cells. The other tube was kept anoxic and dark. Afterward cells from both tubes were analyzed for their $\Delta \Psi$ and compared to the untreated cells from before.

\section{Analysis of the Membrane Potential}

The membrane potential was assessed via fluorescence microscopy with two $\Delta \Psi$-sensitive dyes, 3,3'-Diethyloxacarbocyanine Iodide [DiOC $2(3), \mathrm{TCI}$, Germany] and JC-10 (AAT Bioquest, USA) using the same procedure. These lipophilic dyes form self-aggregates upon membrane uptake, which results in a color shift from green to red fluorescence. The appropriate concentrations of the dyes were figured out in a separate set of experiments, and were found to be $150 \mu \mathrm{M}$ for $D$. shibae and E. coli, and $50 \mu \mathrm{M}$ for M. luteus.

The staining procedure was performed with cells from three different energetic states; untreated cells from the exponential growth phase, cells that had been kept anoxic and dark for $2 \mathrm{~h}$, and cells that had been re-aerated and exposed to light after anoxic and dark incubation.

During the following staining process, all cells were also protected from light to prevent photobleaching of the fluorescent dyes and unwanted, light-induced recovery of the cells. Therefore, $500 \mu \mathrm{l}$ of the respective cells $\left(\mathrm{OD}_{436} 2.0\right)$ were transferred to $2 \mathrm{ml}$ reaction tubes each, mixed with $500 \mu \mathrm{l}$ PBS buffer and stained with $\mathrm{DiOC}_{2}(3)$ for $15 \mathrm{~min}$. For the untreated cells complete depletion of oxygen by respiration during staining could be excluded, even for maximum respiration rates (Holert et al., 2011). For the anoxically incubated cells anoxic conditions were maintained during staining by using $\mathrm{N}_{2}$-flushed PBS buffer and dye.

As a result of their double-layered cell membrane Gramnegative organisms like $D$. shibae tend to take up cyanine dyes worse than Gram-positives (Novo et al., 1999). To overcome this $1 \mathrm{mM}$ EDTA was added prior to staining, which significantly improved the staining results for the Gram-negative strains D. shibae and E. coli (Dumas et al., 2010) by weakening the outer bacterial membrane (Alakomi et al., 2006). The Gram-positive strain $M$. luteus was used for control experiments.

After staining, $10 \mu \mathrm{l}$ of the cell suspension was transferred onto object microscope slides and analyzed under a fluorescence microscope (Leica DMRB, Leitz) at excitation wavelength of $450-490 \mathrm{~nm}$, dichroic filter $510 \mathrm{~nm}$, longpass filter $515 \mathrm{~nm}$ (Leica-Nr.: 513808). At this excitation the normally green fluorescence $(488-530 \mathrm{~nm})$ shifts to red $(>600 \mathrm{~nm})$ when the dye is taken up by the cells due to their membrane potential (Novo et al., 1999). Pictures were taken with an EOS 600 D 
camera using the EOS utility software (ver. 2.10.2.0). Final image processing was performed with PICOLAY (Cypionka et al., 2016). The quantification of the \% of red stained cells was done with CountThem (Cypionka, 2011).

\section{$\Delta \Psi$-Dissipating Agents}

Carbonyl cyanide m-chlorophenyl hydrazone (CCCP), $3,3^{\prime}, 4^{\prime}, 5$-tetrachlorosalicylanilide (TCS) and gramicidin were used for the disruption of $\Delta \Psi$. Samples were treated as described before and subsequently analyzed with fluorescent microscopy. The ionophores were added prior to staining and the samples were incubated $5 \mathrm{~min}$ at room temperature in the dark. Applied concentrations were $2 \mu \mathrm{M}$ CCCP, $2 \mu \mathrm{M}$ TCS, and $5 \mu \mathrm{g} / \mathrm{ml}$ gramicidin. In control experiments, the solvent DMSO did not have any influence without the inhibitors.

\section{RESULTS}

\section{The Intracellular pH of Dinoroseobacter shibae Is Independent of the Energetic State}

In order to determine the intracellular $\mathrm{pH}\left(\mathrm{pH}_{\mathrm{i}}\right)$ of $D$. shibae we used butanol ( $5 \% \mathrm{vol} / \mathrm{vol})$ for membrane permeabilization. Butanol treatment resulted in alkalinization of the suspension when the initial $\mathrm{pH}$ was below 7.2 and in acidification of the suspension at $\mathrm{pH}$ values above 7.4. For the initial $\mathrm{pH}$ of 7.3 only minimal changes were observed after butanol treatment, varying slightly between repeated experiments (Figure 1). Thus, the $\mathrm{pH}_{\mathrm{i}}$ was determined to lie between 7.2 and 7.4. This result was identical for all D. shibae cells, including untreated-, anoxically incubated- and subsequently re-aerated cells. This indicates that the $\mathrm{pH}_{\mathrm{i}}$ in $D$. shibae is independent of the energetic state. For
E. coli a $\mathrm{pH}_{\mathrm{i}}$ between 7.5 and 7.6 was determined with the same technique, confirming literature values (Wilks and Slonczewski, 2007).

\section{Short-term Anoxia Causes a Boost of the Membrane Potential of Dinoroseobacter shibae}

The membrane potential was visualized with two fluorescent carbocyanine dyes, $\mathrm{DiOC}_{2}(3)$ and JC-10. The accumulation of $\mathrm{DiOC}_{2}(3)$ underwent major changes between oxygen availability and anoxia. Freshly harvested cells of D. shibae stained moderately red, indicating the standard state of the membrane potential (Figure 2A). After anoxic incubation, cells stained more intensely red indicating increased $\Delta \Psi$ (Figure 2B). Cells that were aerated after anoxic incubation, again showed moderate dye uptake and red fluorescence, similar to untreated cells (Figure 2C). A quantitative measure by image analysis shows that the amount of red stained cells increases about 2.5-fold during anoxia (Figure 3). These results were confirmed with the alternative fluorescent dye JC-10, although the fluorescence was a little weaker in intensity as with $\mathrm{DiOC}_{2}(3)$ (Supplement 3). This shows that the uptake and intracellular accumulation of $\Delta \Psi$-dependent dyes in $D$. shibae changes significantly between oxic and anoxic conditions suggesting an increased $\Delta \Psi$ in anoxic cells. The outcome of the staining was independent of the presents or absence of succinate, which was used as the cells sole electron and carbon source during cultivation. Furthermore, the increase of $\Delta \Psi$ during anoxia could be observed for varying external $\mathrm{pH}$ values. With a $\mathrm{pH}$ of 7.5 , the growth medium of D. shibae is more alkaline than the $\mathrm{pH}_{\mathrm{i}}$ (near 7.3). We obtained the same results with cells that were grown and tested at $\mathrm{pH}$ 7.0. Even at an external pH of 6.5, which is slightly below the pH optimum of D. shibae (Biebl et al., 2005), the effect was still

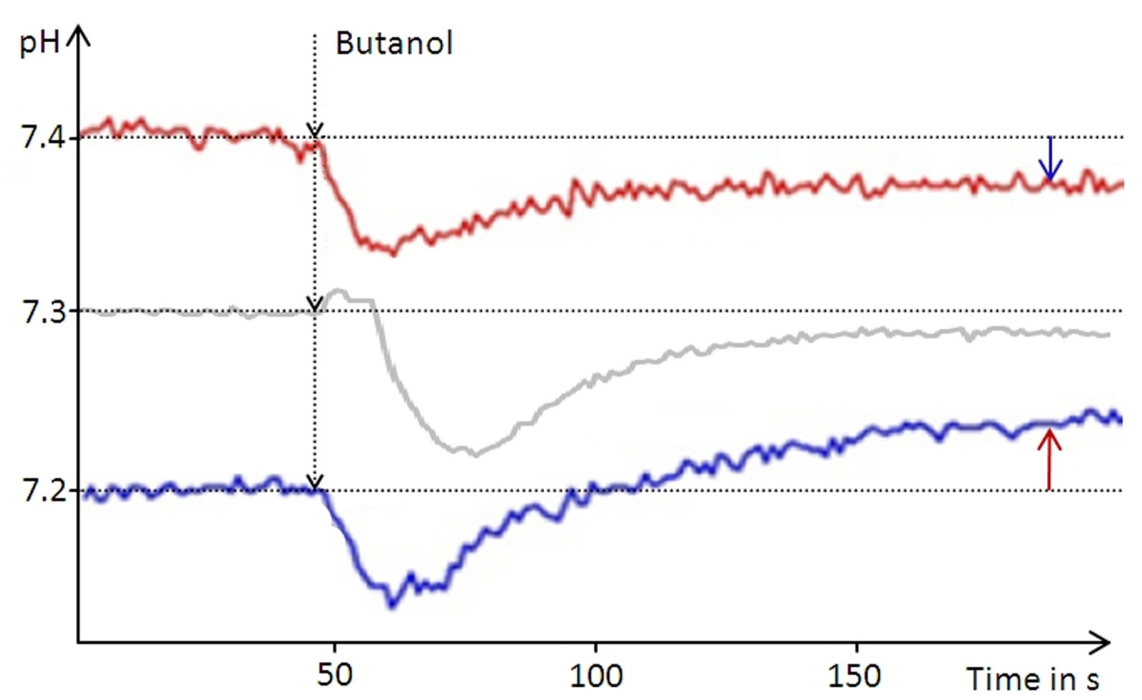

FIGURE 1 | Narrowing down the intracellular pH of $\boldsymbol{D}$. shibae. The $\mathrm{pH}$ of an unbuffered cell suspension was constantly recorded during butanol treatment leading to leakage of the cells. Arrows indicate the direction of the $\mathrm{pH}$ change from the respective starting $\mathrm{pH}$ of the suspension (red graph 7.4, blue graph 7.2) toward the intracellular $\mathrm{pH}$ of 7.3. At the starting $\mathrm{pH}$ of 7.3 the $\mathrm{pH}$ change is very small and can vary between the experiments. 


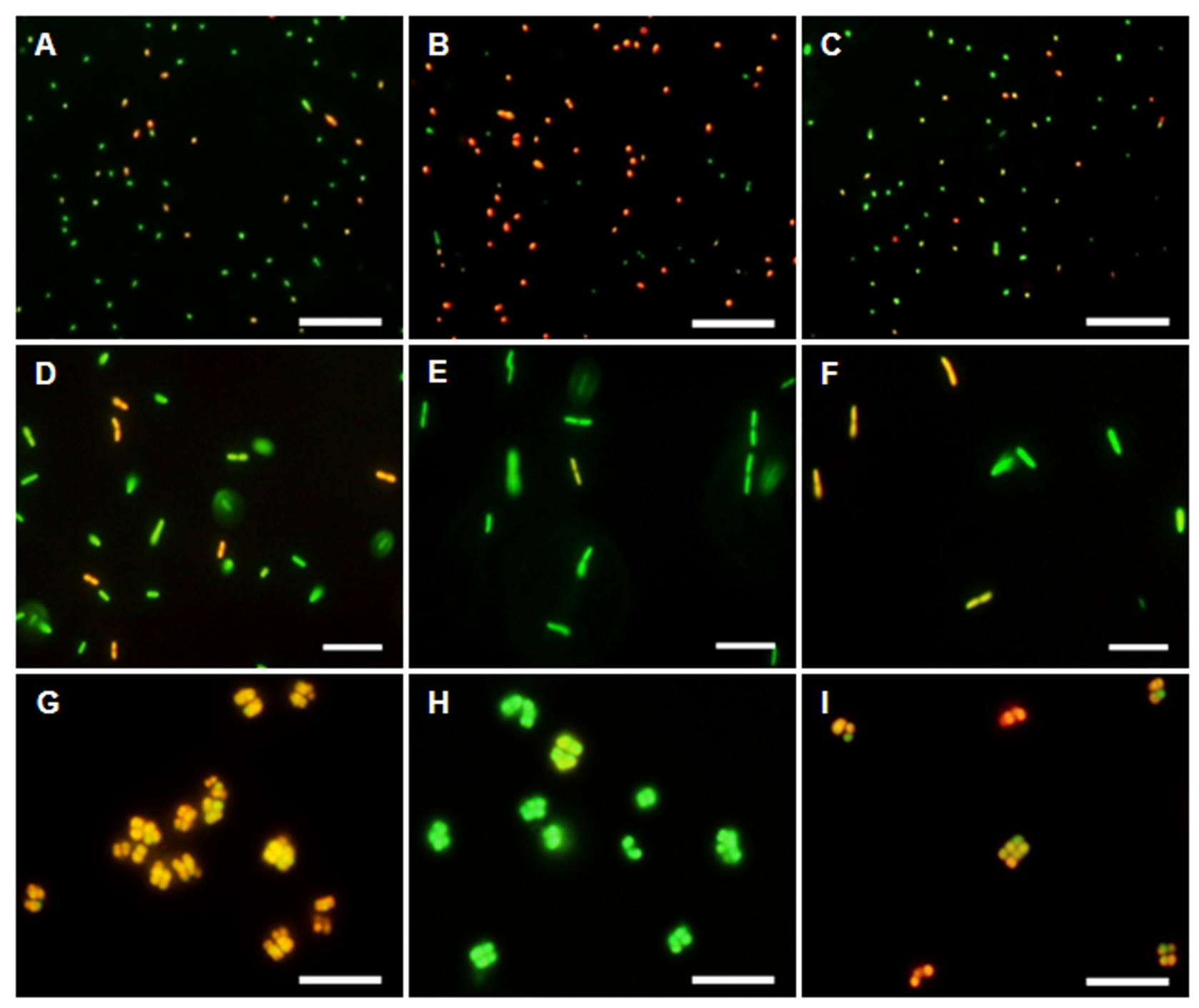

FIGURE 2 | $\mathrm{DiOC}_{2}$ (3)-uptake at different energetic states. (Left column) Untreated cells in exponential growth phase. (Middle column) Cells after $2 \mathrm{~h}$ of $\mathrm{N}_{2}$-gassing. (Right column) Cells after $2 \mathrm{~h} \mathrm{~N} \mathrm{~N}_{2}$-gassing, aerated for 2 min subsequently. (A-C) Dye uptake of $D$. shibae increases after $\mathrm{N}_{2}$-gassing but declines after subsequent aeration. (D-F) Dye uptake of $E$. coli decreases after $\mathrm{N}_{2}$-gassing, but increases after subsequent aeration. (G-I) Dye uptake of $M$. luteus was strongest at the start, decreased drastically after $\mathrm{N}_{2}$-gassing, but increases after subsequent aeration. All scales: $10 \mu \mathrm{m}$.

observed. However, these cells appeared more orange than red. (Supplement 4).

\section{Bacteria in Control Experiments Showed Stable- or Decreased $\Delta \Psi$ during Anoxia}

The observation of an increasing $\Delta \Psi$ for $D$. shibae under anoxic conditions was unexpected. To clarify this behavior we analyzed the $\Delta \Psi$ of other bacteria under the same conditions. E. coli revealed a decrease in $\Delta \Psi$ during shortterm anoxia (Figures 2D-F) with about 2.5 times less red stained cells (Figure 3). The strictly aerobe $M$. luteus (Woodward and Kell, 1991), which took up the dye very well from the start, showed a drastically decreased $\Delta \Psi$ after $\mathrm{N}_{2}$-gassing (Figures 2G-I), with five times less red stained cells (Figure 3). Unlike D. shibae, none of the tested control organisms showed an increased $\Delta \Psi$ during oxic or anoxic conditions.

\section{Protonophore Treatment Proves $\Delta \Psi$-Depending Dye Uptake}

Control experiments with protonophores were conducted to make sure the observed uptake of the dye is indeed $\Delta \Psi$-depending. In all tested organisms dye uptake was drastically decreased and red fluorescence was prevented almost completely when the cells were pre-incubated with the protonophores CCCP or TCS for $5 \mathrm{~min}$ (Figure 4). The channel-forming peptide gramicidin did not work as effective for the Gram-negative bacteria $D$. shibae and E. coli, but worked fine on the Grampositive $M$. luteus. With gramicidin, the amount of $D$. shibae cells stained red/orange decreased from previously mentioned 


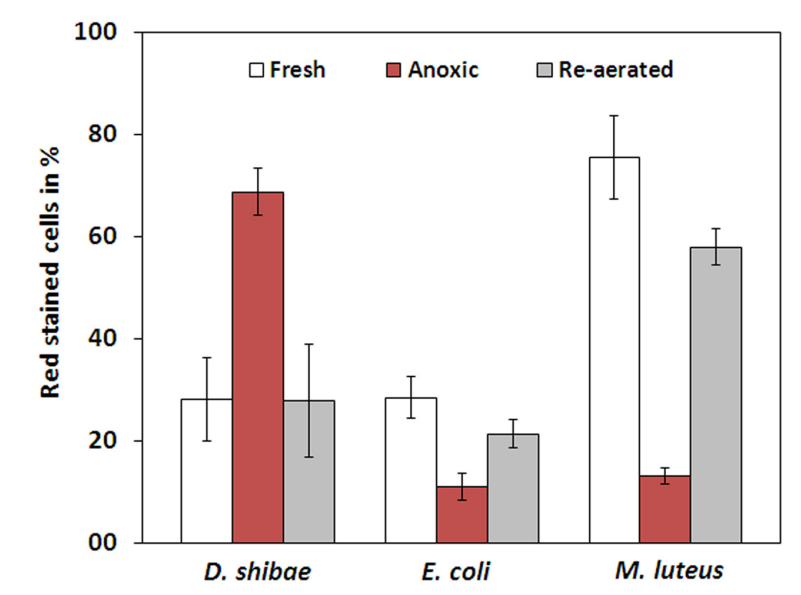

FIGURE 3 | Fraction of red stained cells for fresh, anoxic, and re-aerated cells. $D$. shibae has 2.5 -fold more red stained cells during anoxia, compared to fresh cells and after re-aeration. E. coli has 2.5 -fold and M. luteus even 5-fold less red stained cells during anoxia. All strains approach their original value after re-aeration.

$69( \pm 5) \%$ to $41( \pm 1) \%$. For M. luteus all cells appeared green with no visible dye aggregation.

\section{DISCUSSION}

In the present study, we show that the membrane potential $\Delta \Psi$ of D. shibae is strongly influenced by short-term anoxia - although in an unexpected way - while $\Delta \mathrm{pH}$ is not affected. The used carbocyanine dyes for $\Delta \Psi$-visualization are usually applied in combination with flow cytometry (Novo et al., 1999; Jiao et al., 2004; Zhen et al., 2014). We have shown that fluorescence microscopy can be a useful alternative, since it produces in vivo pictures of $\Delta \Psi$-caused dye-uptake (Supplement 5).

\section{$\Delta \mathrm{pH}$ Is Not Contributing to ATP Recovery}

Different from our expectations, $\Delta \mathrm{pH}$ is seemingly not contributing to the quick ATP recovery of $D$. shibae. Instead the intracellular $\mathrm{pH}$ was determined to be near 7.3, and was not affected from short-term anoxia and re-aeration. The intracellular $\mathrm{pH}$ was lower than that of the medium $(\mathrm{pH} 7.5)$, resulting even in a slightly reversed $\Delta \mathrm{pH}$. We conclude that $\Delta \mathrm{pH}$ does not support proton-driven ATP synthesis in D. shibae. Instead, our results suggest that the proton-motive force relies mainly on $\Delta \Psi$.

\section{Boosted Membrane Potential Supports ATP Regeneration}

According to our expectation short-term anoxia had an impact on $\Delta \Psi$. However, $D$. shibae increased its membrane potential as reaction to short-term anoxia and the resulting ATP depletion, while $\Delta \mathrm{pH}$ remained unchanged. An increasing membrane potential as a response to anoxia is unusual, as indicated by the analyzed control organisms. None of them showed a comparable reaction to short-term anoxia. It was shown before that $D$. shibae
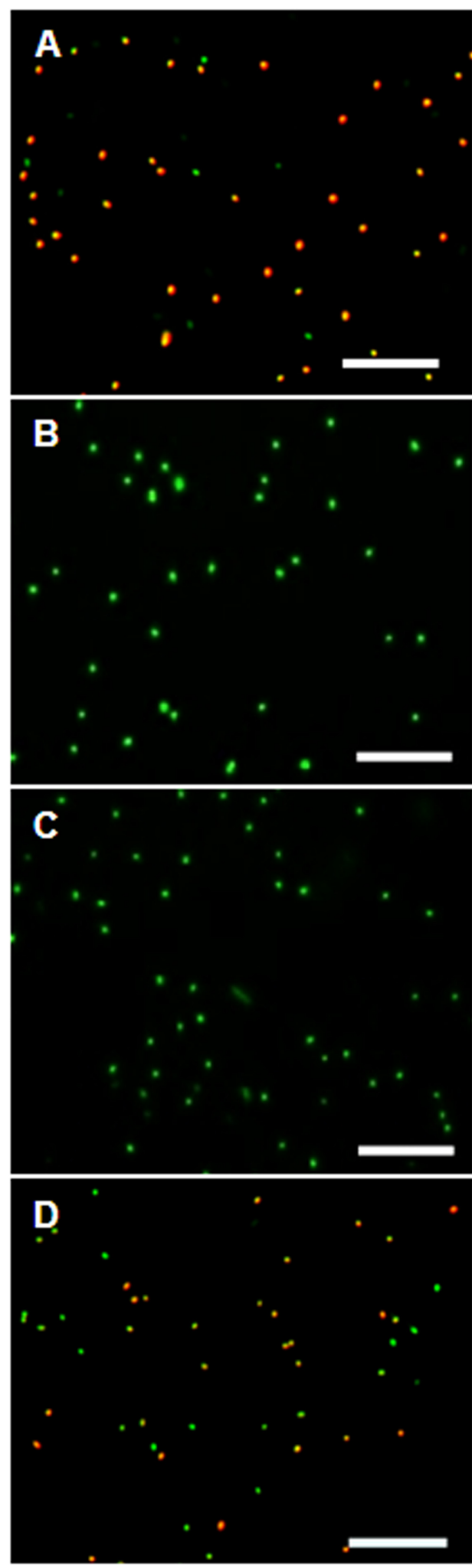

FIGURE 4 | The effect of $\Delta \Psi$-dissipating agents on the DiOC $_{2}$ (3)-uptake of $\boldsymbol{D}$. shibae cells. (A) D. shibae cells with increased membrane potential. (B) $2 \mu \mathrm{M}$ CCCP. (C) $5 \mu \mathrm{M}$ TCS. (D) $5 \mu \mathrm{g} / \mathrm{ml}$ gramicidin. All scales: $10 \mu \mathrm{m}$. 
cells undergo a metabolic crisis during the absence of oxygen and metabolites start to accumulate (Laass et al., 2014). We show that this crisis is also reflected on a bioenergetic and physiological level. The previously documented drop in the ATP content (Holert et al., 2011) and the newly found increase in membrane potential are tied together and a result of the cells' adaptation to anoxia. Like the metabolic crisis, the increased $\Delta \Psi$ normalizes with re-aeration. However, it is still unclear how the process of increasing $\Delta \Psi$ works in detail. Our results suggest an electrogenic mechanism as a response to anoxia. Apparently, the process is not electron-donor dependent, as it was independent of succinate availability.

A boosted membrane potential can give the ATP regeneration of $D$. shibae a flying start, once oxygen becomes available again. The membrane potential is known to be the more potent component of the proton-motive force for bacteria that live in pH-neutral environments (Krulwich et al., 2011). The bioenergetic kickstart is beneficial for $D$. shibae with respect to its natural environment. Diurnal alterations in oxygen availability are very common in phototrophic biofilms (Steunou et al., 2008). D. shibae is abundant in this habitat as a dinoflagellate epibiont (Biebl et al., 2005; Parsons and Preskitt, 2007) and being able to adapt to these alteration is advantageous for its survival (Wagner-Döbler et al., 2010).

However, $\Delta \Psi$ cannot be solely responsible for the observed ATP regeneration capacity. It is build up by a remarkably low amount of charges per cell and has about $-135 \mathrm{mV}$ in its normal state (Krulwich et al., 2011). Assuming the cell size described by Biebl et al. (2005) and the standard membrane capacity ( $1 \mu \mathrm{F} / \mathrm{cm}^{2}$, Adrian, 1980), about $3310^{3}$ charges would be required to increase $\Delta \Psi$ by $-180 \mathrm{mV}$. With an $\mathrm{H}^{+} / \mathrm{ATP}$ ratio of 4 (Elston et al., 1997) the cell could regenerate about $48 \mu \mathrm{M}$ of intracellular ATP. In order to regenerate $12 \mathrm{mM}$ of ATP (Holert et al., 2011), the process must be quickly supported by respiration- or light-driven proton translocation.

\section{REFERENCES}

Adrian, R. H. (1980). "The capacity of cell membranes: gating current measurements," in Developments in Biophysical Research, eds A. Borsellino, P. Omodeo, R. Strom, A. Vecli, and E. Wanke (New York, NY: Springer), 49-55. doi: 10.1007/978-1-4684-1077-8_6

Alakomi, H. L., Paananen, A., Suihko, M. L., Helander, I. M., and Saarela, M. (2006). Weakening effect of cell permeabilizers on gram negative bacteria causing biodeterioration. Appl. Environ. Microbiol. 72, 4695-4703. doi: 10.1128/ AEM.00142-06

Batzke, A., Engelen, B., Sass, H., and Cypionka, H. (2007). Phylogenetic and physiological diversity of cultured deep-biosphere bacteria from equatorial pacific ocean and Peru margin sediments. Geomicrobiol. J. 24, 261-273. doi: 10.1080/01490450701456453

Béjà, O., Suzuki, M. T., Heidelberg, J. F., Nelson, W. C., Preston, C. M., Hamada, T., et al. (2002). Unsuspected diversity among marine aerobic anoxygenic phototrophs. Nature 415, 630-633. doi: 10.1038/415630a

Biebl, H., Allgaier, M., Tindall, B. J., Koblizek, M., Lünsdorf, H., Pukall, R., et al. (2005). Dinoroseobacter shibae gen. nov., sp. nov., a new aerobic phototrophic bacterium isolated from dinoflagellates. Int. J. Syst. Evol. Microbiol. 55, 1089-1096. doi: 10.1099/ijs.0.63511-0

Cypionka, H. (2005). Mpwin Software. Vers. 2008.08.25. Available at: www.pmbio. icbm.de/downlist.htm
The increased $\Delta \Psi$ during anoxia cannot possibly be caused by the $\Delta \mathrm{pH}$. A $\Delta \mathrm{pH}$ value of 0.5 could at maximum builds up $30 \mathrm{mV}$ membrane potential. We observed the $\Delta \Psi$ increase at favorable and unfavorable $\Delta \mathrm{pH}$ values above and below the intracellular $\mathrm{pH}$. This demonstrates that the documented effect is significantly larger than $30 \mathrm{mV}$ and based on a different mechanism.

\section{AUTHOR CONTRIBUTIONS}

CK concept, experiments, data analysis, and wrote manuscript. $\mathrm{HC}$ concept and wrote manuscript.

\section{FUNDING}

This study has been funded by the German Science Foundation within the Collaborative Research Centre SFB-TRR51 (Roseobacter).

\section{ACKNOWLEDGMENTS}

We thank Robert Strodel and Minh Dang Nguyen for support during the lab work, as well as Johannes Holert and Elisabeth Härtig for comments on the manuscript. We are also grateful for the technical assistance by Frank Meyerjürgens and Jana Schmidt.

\section{SUPPLEMENTARY MATERIAL}

The Supplementary Material for this article can be found online at: http://journal.frontiersin.org/article/10.3389/fmicb. 2017.00695/full\#supplementary-material

Cypionka, H. (2011). CountThem Software. Vers. 2011.08.18. Available at: www. pmbio.icbm.de/downlist.htm

Cypionka, H., Völcker, E., and Rohde, M. (2016). Erzeugung virtueller 3D-Bilder mit jedem Lichtmikroskop oder REM. BIOspektrum 22, 143-145. doi: 10.1007/ s12268-016-0668-1

Dumas, E., Gao, C., Suffern, D., Bradforth, S., Dimitrijevic, N., and Nadeau, J. (2010). Interfacial charge transfer between CdTe quantum dots and Gram negative vs Gram positive bacteria. Environ. Sci. Technol. 44, 1464-1470. doi: $10.1021 /$ es $902898 \mathrm{~d}$

Elston, T., Wang, H., and Oster, G. (1997). Energy transduction in ATP synthase. Nature 391, 510-513. doi: 10.1038/35185

Holert, J., Hahnke, S., and Cypionka, H. (2011). Influence of light and anoxia on chemiosmotic energy conservation in Dinoroseobacter shibae. Environ. Microbiol. Rep. 3, 136-141. doi: 10.1111/j.1758-2229.2010.00199.x

Jiao, N., Yang, Y., and Luo, T. (2004). Membrane potential based characterization by flow cytometry of physiological states in an aerobic anoxygenic phototrophic bacterium. Aquat. Microb. Ecol. 37, 149-158. doi: 10.3354/ame037149

Kolber, Z. S., Plumley, F. G., Lang, A. S., Beatty, J. T., Blankenship, R. E., VanDover, C. L., et al. (2001). Contribution of aerobic photoheterotrophic bacteria to the carbon cycle in the ocean. Science 292, 2492-2495. doi: 10.1126/science.1059707

Krulwich, A., Sachs, G., and Padan, E. (2011). Molecular aspects of bacterial pH sensing and homeostasis. Nat. Rev. Microbiol. 9, 330-343. doi: 10.1038/ nrmicro2549 
Laass, S., Kleist, S., Bill, N., Druppel, K., Kossmehl, S., Wohlbrand, L., et al. (2014). Gene regulatory and metabolic adaptation processes of Dinoroseobacter shibae DFL12T during oxygen depletion. J. Biol. Chem. 289, 13219-13231. doi: 10.1074/jbc.M113.545004

Novo, D., Perlmutter, N., Hunt, R., and Shapiro, H. (1999). Accurate flow cytometric membrane potential measurement in bacteria using diethyloxacarbocyanine and a ratiometric technique. Cytometry 35, 55-63. doi: 10.1002/(SICI)1097-0320(19990101)35:1<55::AID-CYTO8>3.0.CO;2-2

Parsons, M. L., and Preskitt, L. B. (2007). A survey of epiphytic dinoflagellates from the coastal waters of the island of Hawai'i. Harmful Algae 6, 658-669. doi: 10.1016/j.hal.2007.01.001

Piekarski, T., Buchholz, I., Drepper, T., Schobert, M., Wagner-Döbler, I., Tielen, P., et al. (2009). Genetic tools for the investigation of Roseobacter clade bacteria. BMC Microbiol. 9:265. doi: 10.1186/1471-21809-265

Scholes, P., and Mitchell, P. (1970). Acid-base titration across the plasma membrane of Micrococcus denitrificans: factors affecting the effective proton conductance and the respiratory rate. J. Bioernerg. 1, 61-72. doi: 10.1007/ BF01516089

Soora, M., and Cypionka, H. (2013). Light Enhances Survival of Dinoroseobacter shibae during long-term starvation. PLoS ONE 8:e57487. doi: 10.1371/journal. pone. 0057487

Steunou, A. S., Jensen, S. I., Brecht, E., Becraft, E. D., Bateson, M. M., Kilian, O., et al. (2008). Regulation of nif gene expression and the energetics of N2 fixation over the diel cycle in a hot spring microbial mat. ISME J. 2, 364-378. doi: 10.1038/ismej.2007.117
Wagner-Döbler, I., Ballhausen, B., Berger, M., Brinkhoff, T., Buchholz, I., Bunk, B., et al. (2010). The complete genome sequence of the algal symbiont Dinoroseobacter shibae: a hitchhiker's guide to life in the sea. ISME J. 4, 61-77. doi: 10.1038/ismej.2009.94

Wilks, J., and Slonczewski, L. (2007). pH of the cytoplasm and periplasm of Escherichia coli: rapid measurement by green fluorescent protein fluorimetry. J. Bacteriol. 189, 5601-5607. doi: 10.1128/JB.00615-0

Woodward, A. M., and Kell, D. B. (1991). On the relationship between the nonlinear dielectric properties and respiratory activity of the obligately aerobic bacterium Micrococcus luteus. J. Electroanal. Chem. Interfacial Electrochem. 321.3, 423-439.

Zhen, Y. F., Wang, G. D., Zhu, L. Q., Tan, S. P., Zhang, F. Y., Zhou, X. Z., et al. (2014). P53 dependent mitochondrial permeability transition pore opening is required for dexamethasone-induced death of osteoblasts. J. Cell. Physiol. 229, 1475-1483. doi: 10.1002/jcp.24589

Conflict of Interest Statement: The authors declare that the research was conducted in the absence of any commercial or financial relationships that could be construed as a potential conflict of interest.

Copyright $\odot 2017$ Kirchhoff and Cypionka. This is an open-access article distributed under the terms of the Creative Commons Attribution License (CC BY). The use, distribution or reproduction in other forums is permitted, provided the original author(s) or licensor are credited and that the original publication in this journal is cited, in accordance with accepted academic practice. No use, distribution or reproduction is permitted which does not comply with these terms. 